\title{
THE EXISTENTIAL SIGNIFICANCE OF CEREMONIAL ARCHES FOR THE ENVIRONMENTAL IMAGE OF THE KERATON AREA IN CIREBON AND YOGYAKARTA
}

\author{
${ }^{1}$ Kirana Zerlinda. ${ }^{2}$ Ir. FX. Budiwidodo P, MSP., IAP. \\ ${ }^{1}$ Student in the Bachelor's (S-1) Study Program in Architecture at \\ Parahyangan Catholic University \\ ${ }^{2}$ Senior lecturer in the Bachelor's (S-1) Study Program in Architecture at \\ Parahyangan Catholic University
}

\begin{abstract}
The Special Region of Yogyakarta (DIY) and the town of Cirebon are places that share the same monarchical background. This has made urban space planning and the lay-out develop certain characteristics leading to a uniqueness or urban identity. This planning has taken on a physical shape discernible in the environmental image. It has been shaped by the local cultural activities. Ceremonial arches (gates called gerbang) can be regarded as physical elements to be found in Cirebon and Yogyakarta that have culturalhistorical value as icons representing the urban environmental image. However, changes made in environmental planning (leading to chaos by prioritizing private interests) has diminished the existence of the physical element of these gerbang At present DIY still adheres to (or recognizes) its monarchical cultural traditions in terms of the public authorities, but Cirebon's case is different. The latter no longer employs the system for public governance of its region, and at present the historiographic remnants have ended up as mere internal assets.

These two differences will naturally affect urban spatial planning and its physical elements, especially when it comes to the characteristic gerbang. In the area of Keraton Kasultanan Ngayogyakarta there are physical elements unlike a proper ceremonial arch, but in socio-cultural terms the Pojok Benteng has been interpreted as a gerbang marking the border of the kingdom's region. On the other hand, in the area of Keraton Kasepuhan, socio-cultural values affect the interpretation of other physical elements as falling under the gerbang category. These ceremonial arches have ended up as mere markers of "thereness" in the palatial area of the Keraton, which is caused by many other factors that hamper these gerbang gates so that there is no more indication of their actual existence.
\end{abstract}

Keywords: Existence, Socio-cultural, Ceremonial Arch, Urban Image, Expression

\section{MAKNA EKSISTENSI GERBANG TERHADAP CITRA LINGKUNGAN KAWASAN KERATON CIREBON \& YOGYAKARTA}

\author{
${ }^{1}$ Kirana Zerlinda. ${ }^{2}$ Ir. FX. Budiwidodo P, MSP., IAP. \\ ${ }^{1}$ Mahasiswa S1 Program Studi Arsitektur Universitas Katolik Parahyangan. \\ 2 Dosen Pembimbing S1 Program Studi Arsitektur Universitas Katolik Parahyangan.
}

\begin{abstract}
Abstrak-Daerah Istimewa Yogyakarta (DIY) dan Kota Cirebon merupakan kota dengan latar belakang monarchi yang masih eksis di Indonesia. Hal tersebut menjadikan tatanan ruang dan elemen fisik kota memiliki karakteristik dan keunikan tersendiri yang dapat disebut juga sebagai identitas kota. Sebuah tatanan ruang dan elemen fisik
\end{abstract}

\footnotetext{
${ }^{1}$ Corresponding author: kirana.zerlinda@gmail.com
} 
perkotaan merupakan bentuk fisik yang dapat dilihat secara visual dari citra suatu lingkungan. Citra lingkungan tersebut terbentuk melalui aktivitas atas budaya warga kotanya.

Gerbang sebagai salah satu elemen fisik di Kota Cirebon dan DIY yang memilki nilai kultural-historis sebagai sosok dari citra lingkungan kota. Namun, perubahan tata-lingkungan yang menuju ke arah kekacauan atau chaos yang mementingkan pentingan pribadi membuat eksistensi dari elemen fisik gerbang berkurang.

Daerah Istimewa Yogyakarta (DIY) saat ini masih menganut atau mengakui kultur dan budaya monarchical dalam hal kewenangan publik kewilayahannya, berbeda halnya dengan Kota Cirebon yang sudah tidak lagi menggunakan sistem kewenangan publik kewilayahannya. Saat ini peninggalan bersifat historigrafis hanya menjadi aset internal saja. Kedua perbedaan tersebut mempengaruhi tatanan ruang dan elemen fisik perkotaannya terutama pada elemen gerbang.

Pada Kawasan Keraton Kasultanan Ngayogyakarta terdapat elemen fisik yang secara bentuk tidak seperti gerbang pada umumnya, namun secara sosial dan budaya, Pojok Benteng telah ditafsirkan menjadi gerbang yang membatas wilayah kerajaan. Kawasan Keraton Kasepuhan tidak ditemukan nilai sosial budaya yang berpengaruh pada penafsiran elemen fisik lain sebagai gerbang. Dimana gerbang hanyalah menjadi penanda "kedisinian" pada kawasan keraton dikarenakan banyak elemen lain yang menghalangi gerbang sehingga tidak menunjukkan adanya eksistensi dari gerbang tersebut.

Kata-kata Kunci: Eksistensi, Sosial-Budaya, Gerbang, Citra Kota, Ekspresi, Kota Yogyakarta, Kota Cirebon

\section{PENDAHULUAN}

Daerah Istimewa Yogyakarta (DIY) dan Kota Cirebon merupakan kota dengan latar belakang monarchi yang masih eksis di Indonesia. Hal tersebut menjadikan tatanan ruang dan elemen fisik kota memiliki bentuk fisik yang dapat dilihat secara visual dari citra suatu lingkungan. Citra lingkungan tersebut terbentuk melalui aktivitas atas budaya warga kotanya.

Fenomena penekanan unsur modernitas terhadap tatanan ruang dan elemen fisik kota dengan nyata dapat terlihat. Saat ini nilai-nilai kultural historis telah luput dari jiwa warga Kota Cirebon dan DIY. Dan pembangunan yang tidak terkontrol dalam aspek kelegalan oleh pemerintah dapat merusak citra lingkungan yang telah ada.

Gerbang di Kota Cirebon dan DIY memilki nilai kultural-historis sebagai sosok dari citra lingkungan kota. Namun, perubahan tata-lingkungan yang menuju ke arah kekacauan yang mementingkan pentingan pribadi membuat eksistensi dari elemen fisik gerbang berkurang.

Pengalaman ruang yang menggugah hati dan perasaan yang mengalaminya menjadi salah satu hal yang dapat menjadikan eksistensi suatu elemen fisik semakin nyata. Gerbang sebagai pembatas ruang dapat memunculkan rasa dan kejutan dari ruang dalam dan luar yang dibatasinya.

Daerah Istimewa Yogyakarta (DIY) saat ini masih menganut atau mengakui kultur dan budaya monarchical dalam hal kewenangan publik kewilayahannya, sedangkan Kota Cirebon sudah tidak lagi menggunakan sistem kewenangan publik kewilayahannya, saat ini peninggalan bersifat historigrafis hanya menjadi aset internal saja. Kedua perbedaan tersebut tentunya akan mempengaruhi tatanan ruang dan elemen fisik perkotaannya terutama pada elemen gerbang.

Tujuan penelitian ini adalah untuk mengetahui citra lingkungan yang terbentuk dari elemen fisik gerbang melalui pengalaman ruangnya serta mendeskripsikan ekspersi ruang sekitar dan sosoknya. Manfaat dari penelitian ini adalah diharapkan dapat menjadi acuan penelitian yang akan datang untuk dapat lebih dikembangkan serta dapat menambah kajian literatur untuk segala kalangan masyarakat agar dapat menjaga dan melestarikan identitas akan nilai kultural kota. 


\section{TEORI PRINSIP EKSISTENSI DALAM MENCIPTAKAN CITRA LINGKUNGAN PERKOTAAN \\ 2.1 PRINSIP DASAR EKSISTENSI DALAM ARSITEKTUR}

Ruang eksistensial telah didefinisikan sebagai sistem dengan persepsi yang relatif dirasakan oleh manusia atau juga dapat sebagai "citra" dari suatu lingkungan atau ruang tertentu (Schulz, 1971). Dasar-dasar elemen yang mempengaruhi eksistensial dalam arsitektur adalah centre atau place (proximity), direction atau path (continuity) dan area atau domains (enclosure).

Centre and Place. Place disini merupakan sebuah tujuan atau fokus dimana pengamat akan mengalami rasa yang bermakna atas keberadaan atau eksistensi dari tempat atau objek yang ditujunya.

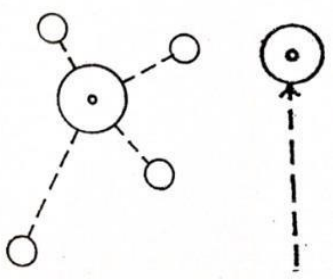

Figur 1 Ilustrasi Centre and Place

Direction and Path. Arah secara horizontal dan vertikal dalam suatu tempat atau objek dapat menciptakan sebuah eksitensi. Arah vertikal menunjukkan sebuah dimensi yang sakral dari sebuah tempat atau objek. Sedangkan arah horizontal merepresentasikan manusia, hubungannya dengan dunia dan segala aktifitasnya.
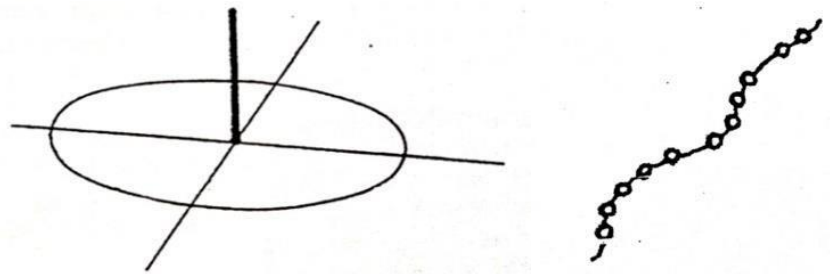

Figur 2. Ilustrasi Direction and Path

Secara persepsi, jalur atau path memiliki karakteristik menerus atau continuity. Jalur sering dibayangkan sebagai suatu rangkaian yang linear. Disitulah jalur menciptakan sebuah akses menuju tujuan dan juga meninggalkan tempat atau ruang lain yang telah dilewati.

Area and Domain. Terkadang suatu area dibatasi oleh elemen alam yang kuat seperti tepi laut, sungai, pegunungan. Area dengan kondisi alam tertentu dapat mempengaruhi aktifitas manusia yang tinggal didalamnya.

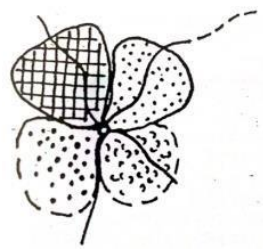

Figur 3 Ilustrasi Area and Domain 
Tingkatan secara hirarki dari eksistensi merupakan sebuah produk dari manusia yang peka terhadap lingkungan ataupun ruang yang mereka alami. Sebuah eksistensi dapat dideskripsikan sebagai gabungan aksi dalam tingkat-tingkat tertentu (secara hirarki) secara dinamis pada suatu media. Melalui persepsi, media tersebut dialami dan dapat dirasakan, namun setiap individu akan mendapatkan persepsi yang berbeda-beda tergantung pada situasi individu tersebut. Tingkatan tersebut dibagi menjadi lima, yaitu The Hand, Furniture, The House, The Urban Level, dan Landscape.

\subsection{PRINSIP DASAR KEESTETIKAAN LINGKUNGAN}

Keestetikaan lingkungan yang dirasakan oleh suatu objek yaitu manusia merupakan hal yang relatif dan argumentatif. Namun terdapat prinsip-prinsip mengenai keestetikan yang dapat dijadikan parameter. Prinsip-prinsip tersebut terbagi ke dalam tiga aspek yaitu kebenaran (truth), kebaikan (goodness) dan keindahan (beauty).

Kata kunci dari estetika adalah keteraturan yang mejadikan prinsip estetika perkotaan dapat diadaptasi dari prinsip perancangan arsitektur yaitu kesatuan (unity), ekspresi (expression), besaran (magnitude), fungsi (function) dan struktur (structure).

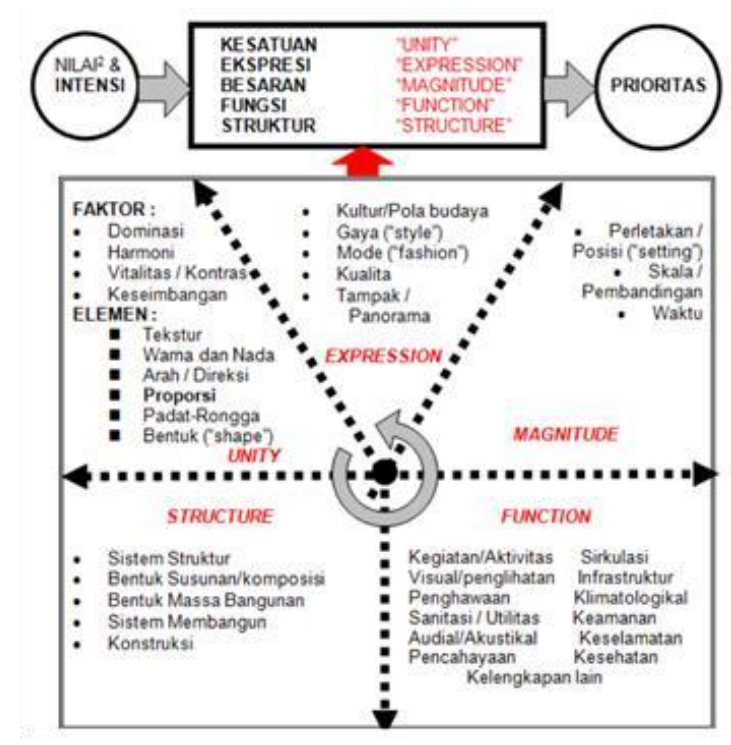

Figur 4. Prinsip Desain Arsitektur

Prinsip ekspresi dalam arsitektur dipengaruhi oleh beberapa faktor yaitu, kultur/ pola budaya, gaya/style, mode/fashion, kualitas dan tampak/ panorama (townscape). Ekspresi juga dapat dipengaruhi oleh faktor lain yang terdapat pada prinsip kesatuan (unity) dan prinsip besaran (magnitude) karena ketifa prinsip ini saling beririsan dalam membentuk estetika lingkungan.

Parameter yang digunakan untuk menganalisa perletakkan dalam lingkungan perkotaan adalah dengan menilai isi/content dari ruang tersebut. Persepsi dari sebuah tempat dipengaruhi oleh apa yang membuat tempat itu 'ini adalah ini, bukan itu'. Prinsip-prinsip mengenai place menurut Gordon Cullen terbagi menjadi tujuh yaitu, keseluruhan sebagai unit, bentuk unit, kekosongan pusatnya, penutup batasnya, hubungan lahan/tampak, perabotan tempat, dan gambaran visual. 


\subsubsection{ASPEK-ASPEK YANG MEMPENGARUHI KARAKTERISTIK VISUAL}

Prinsip dari pengalaman ruang ini diungkapkan oleh Gordon Cullen dalam buku The Concise Townscape. Dengan bergerak atau berjalan dari satu titik ke titik lain, manusia sebagai pengamat akan merasakan sebuah pengalaman ruang secara sequential. Perubahan suasana ruang yang kontras dalam perjalanan tersebut dapat menggugah perasaan pengamat yang mengalami ruang.

\subsubsection{PARAMETER PENILAIAN EKSPRESI BERDASARKAN TEORI SEMANTIK}

Untuk menganalisa proporsi dibutuhkan perhitungan perbandingan antara tinggi dan jarak bangunan $\mathrm{D} / \mathrm{H}$. Kemudian dibutuhkan parameter untuk dapat menilai tingkat keterbukaan. Parameter yang dimaksud adalah sebagai berikut;

Tabel 1 Parameter Penilaian Proporsi D/H

Sumber: Randy, 2015

\begin{tabular}{|l|l|l|}
\hline Nilai & Proporsi D/H & Kesan \\
\hline 2 & $1 / 4$ sampai sama dengan $1 / 2$ & Menekan \\
\hline 1 & $1 / 2$ sampai sama dengan 1 & Intim/Sempit \\
\hline 0 & 1 sampai sama dengan 2 & Netral/ Seimbang \\
\hline-1 & 2 sampai sama dengan 3 & Terbuka \\
\hline-2 & 3 sampai sama dengan 4 & Sangat Luas \\
\hline
\end{tabular}

Untuk mengetahui seberapa besar penguasaan gerbang terhadap ruang terbukanya, diperlukan nilai perbandingan antara lebar gerbang dan lebar jalan serta perbandingan tinggi gerbang dan ketinggian bangunan yang melingkupi ruang terbuka tersebut.

Tabel 2 Parameter Penilaian Perbandingan Lebar Gerbang dan Jalan

\begin{tabular}{|l|l|l|} 
Nilai & Hasil Perbandingan Lebar & Tingkat Eksistensi \\
\hline-1 & $0-0.15$ & Buruk \\
\hline-2 & $0.15-0.25$ & Cenderung buruk \\
\hline 0 & $0.25-0.5$ & Moderat / netral \\
\hline 1 & $0.5-1$ & Cenderung baik \\
\hline 2 & 1 & Baik \\
\hline
\end{tabular}

Tabel 3 Parameter Penilaian Perbandingan Tinggi Gerbang dan Bangunan

\begin{tabular}{|l|l|l|} 
Nilai & Hasil Perbandingan Tinggi & Tingkat Eksistensi \\
\hline-1 & Kurang dari 0.25 & Buruk \\
\hline-2 & $0.25-0.5$ & Cenderung buruk \\
\hline 0 & 1 & Moderat / netral \\
\hline 1 & $1-2$ & Cenderung baik \\
\hline 2 & Lebih dari 2 & Baik \\
\hline
\end{tabular}

\section{PEMBAHASAN}




\subsection{KLASIFIKASI KARAKTERISTIK GERBANG PADA KAWASAN KERATON CIREBON \& YOGYAKARTA}

Penelitian ini merupakan bagian kecil dalam penelitian yang lebih besar yaitu Formulasi Rupa Ruang Kota oleh Ir. FX. Budiwidodo Pangorso, M.Sp, Iap. dengan objek penelitian Kota Cirebon dan Yogyakarta yang merupakan kota dengan nilai kultural historis berbasis monarki.

Metodologi. Jenis penelitian yang dilakukan adalah kualitatif dengan mendeskripsikan ekspresi ruang sekitar dan sosok gerbang terkait pencapaian eksistensi. Pengambilan data dilakukan dengan pengambilan gambar dari jalan dengan sudut pandang pejalan kaki untuk merekam fakta keruangan. Kemudian data yang dihasilkan adalah berupa foto dan sketsa. Analisa dilakukan melalui paparan deskriptif dari ruang sekitar dan sosok gerbang itu sendiri yang didasari oleh pendekatan literatur mengenai teori eksistensi dalam arsitektur, teori estetika lingkungan perkotaan dan prinsip desain.

\subsubsection{KASIFIKASI KARAKTERISTIK GERBANG}

Pada Kawasan Keraton Cirebon terdapat tiga varian yang ditemukan dari klasifikasi perletakkan gerbang, yaitu simpul jalan (node), jalur (path), dan sisi jalan. 


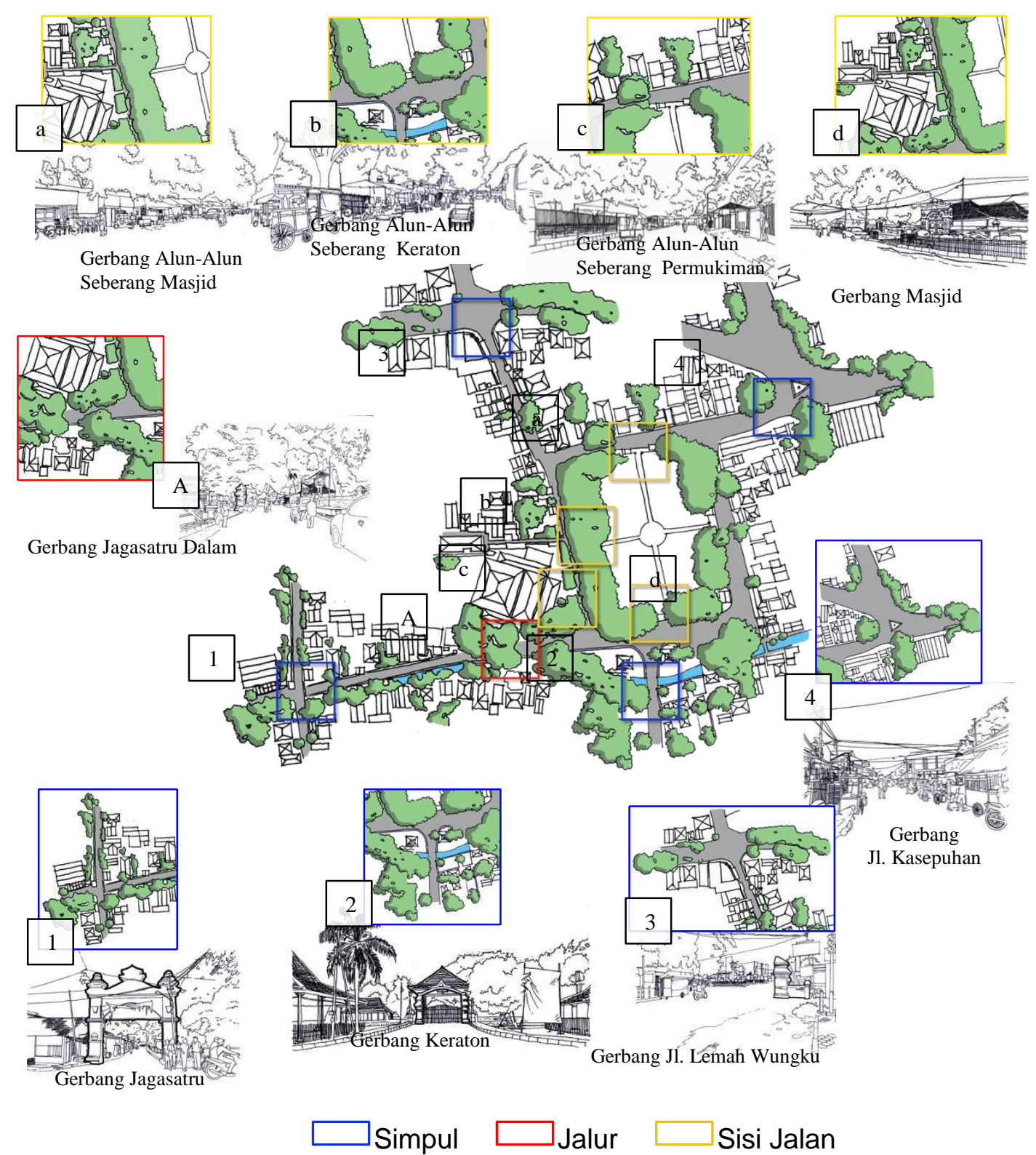

Figur 4 Peta Persebaran Klasifikasi Gerbang Berdasarkan Perletakkan/ Setting Pada Kawasan Keraton Cirebon

Klasifikasi proporsi visual ruang terbuka pada kawasan Keraton Cirebon sangat beragam yaitu ruang yang kurang terdefinisi keruangannya, ruang yang sangat luas, terbuka dan netral. Berikut paparan ragam proporsi ruang terbuka: 


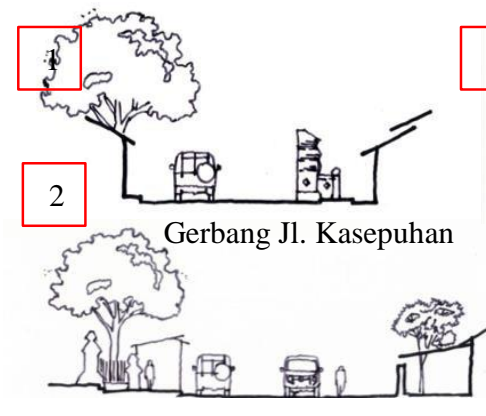

Gerbang Alun-Alun

Seberang Permukiman
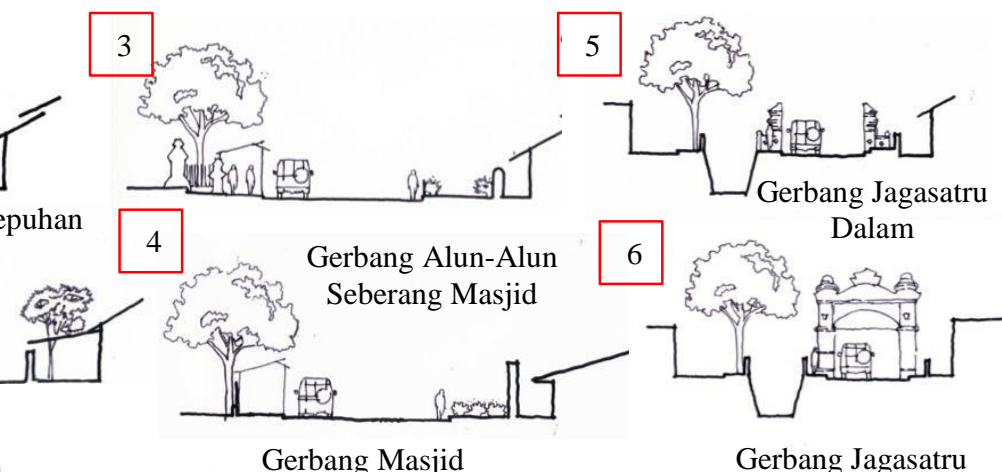

4 Gerbang Alun-Alun 6 Dalam
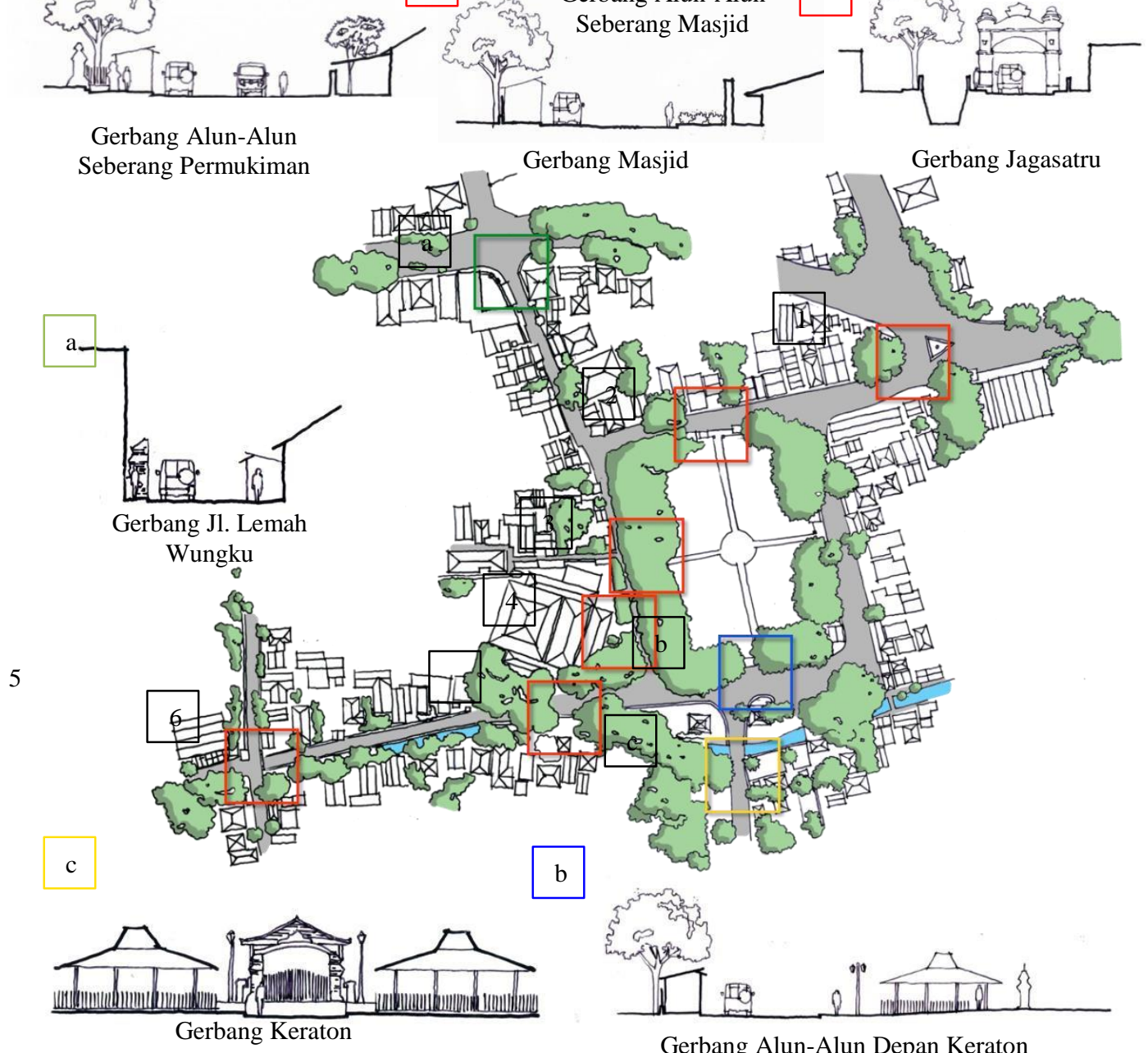

b

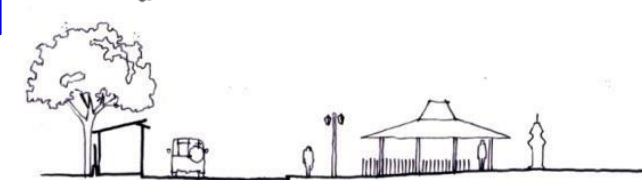

Gerbang Alun-Alun Depan Keraton

Ruang kurang terdefinisi

Sangat Luas

$\square$ Terbuka $\square$ Netral

Figur 5 Peta Persebaran Klasifikasi Gerbang Berdasarkan Proporsi Visual Pada Kawasan Keraton Cirebon

Pada kawasan Keraton Cirebon terdapat tiga varian yang ditemukan dari klasifikasi bentuk gerbang, yaitu garis, bidang, dan volume. Berikut paparan ragam bentuk gerbang di Kawasan Keraton Cirebon. 


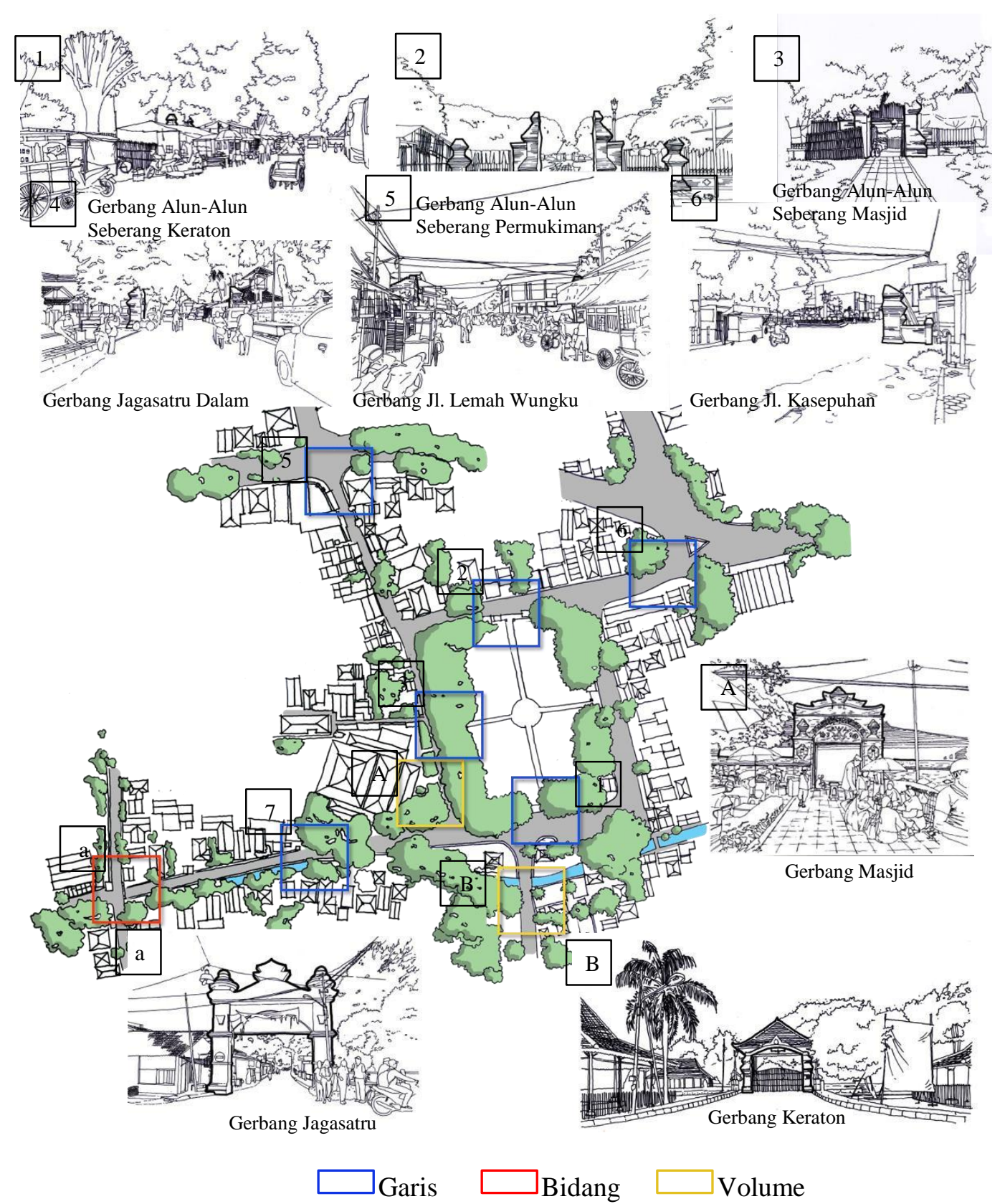

Figur 6 Peta Persebaran Klasifikasi Gerbang Berdasarkan Ekspresi Bentuk Pada Kawasan Keraton Cirebon

Dalam kawasan Keraton Kasultanan Ngayogyakarta terdapat dua belas spot yang akan dilakukan klasifikasi berdasarkan perletakkan/ setting, proporsi visual dan bentuk dari sosok gerbang yang akan memunculkan beberapa varian yang berbeda-beda.

Pada Kawasan Keraton Yogyakarta terdapat tiga varian yang ditemukan dari klasifikasi perletakkan gerbang, yaitu simpul jalan (node), jalur (path), dan sisi jalan. Berikut paparan ragam perletakkan gerbang pada Kawasan Keraton Yogyakarta. 
The existential significance of ceremonial arches for the ...

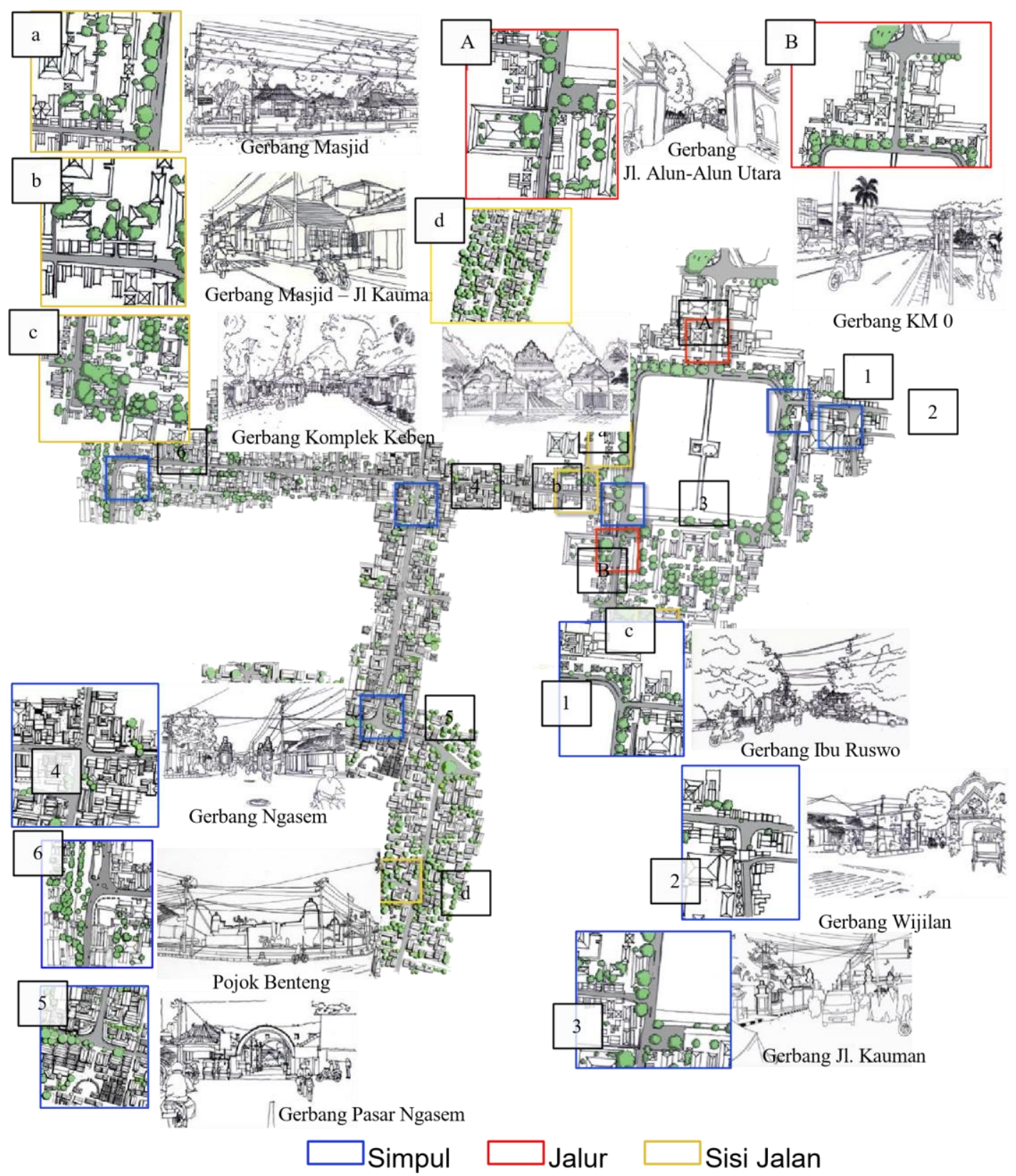

Figur 7 Peta Persebaran Klasifikasi Gerbang Berdasarkan Perletakkan/ Setting Pada Kawasan Keraton Yogyakarta

Klasifikasi proporsi visual ruang terbuka pada kawasan Keraton Yogyakarta sangat beragam. Tiap spot gerbang memiliki keterbukaan ruang yang berbeda-beda. Berikut paparan ragam proporsi ruang terbuka: 


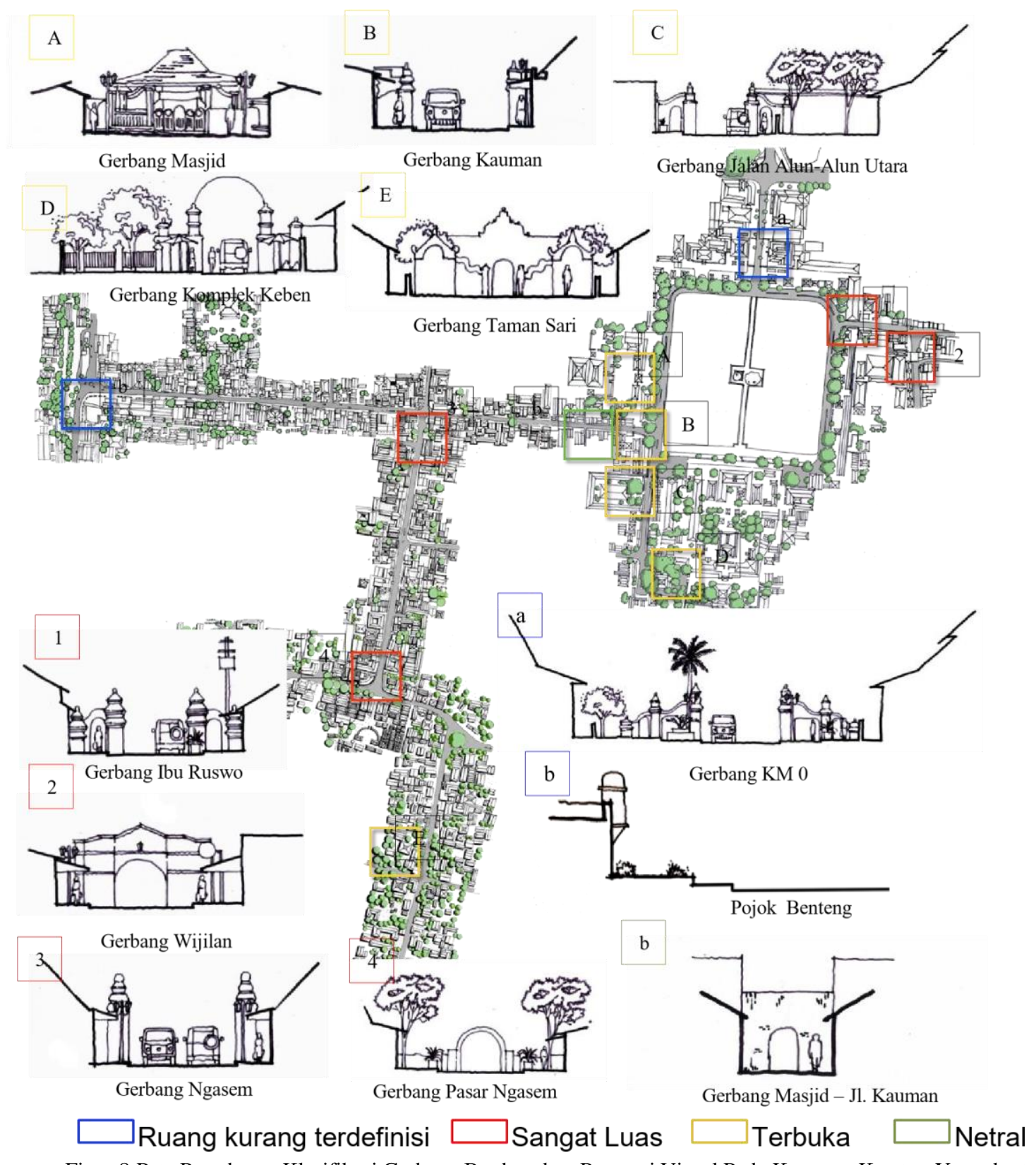

Figur 8 Peta Persebaran Klasifikasi Gerbang Berdasarkan Proporsi Visual Pada Kawasan Keraton Yogyakarta

Pada kawasan Keraton Yogyakarta terdapat tiga varian yang ditemukan dari klasifikasi bentuk gerbang, yaitu garis, bidang, dan volume. Berikut paparan ragam bentuk gerbang di Kawasan Keraton Cirebon. 
The existential significance of ceremonial arches for the ...

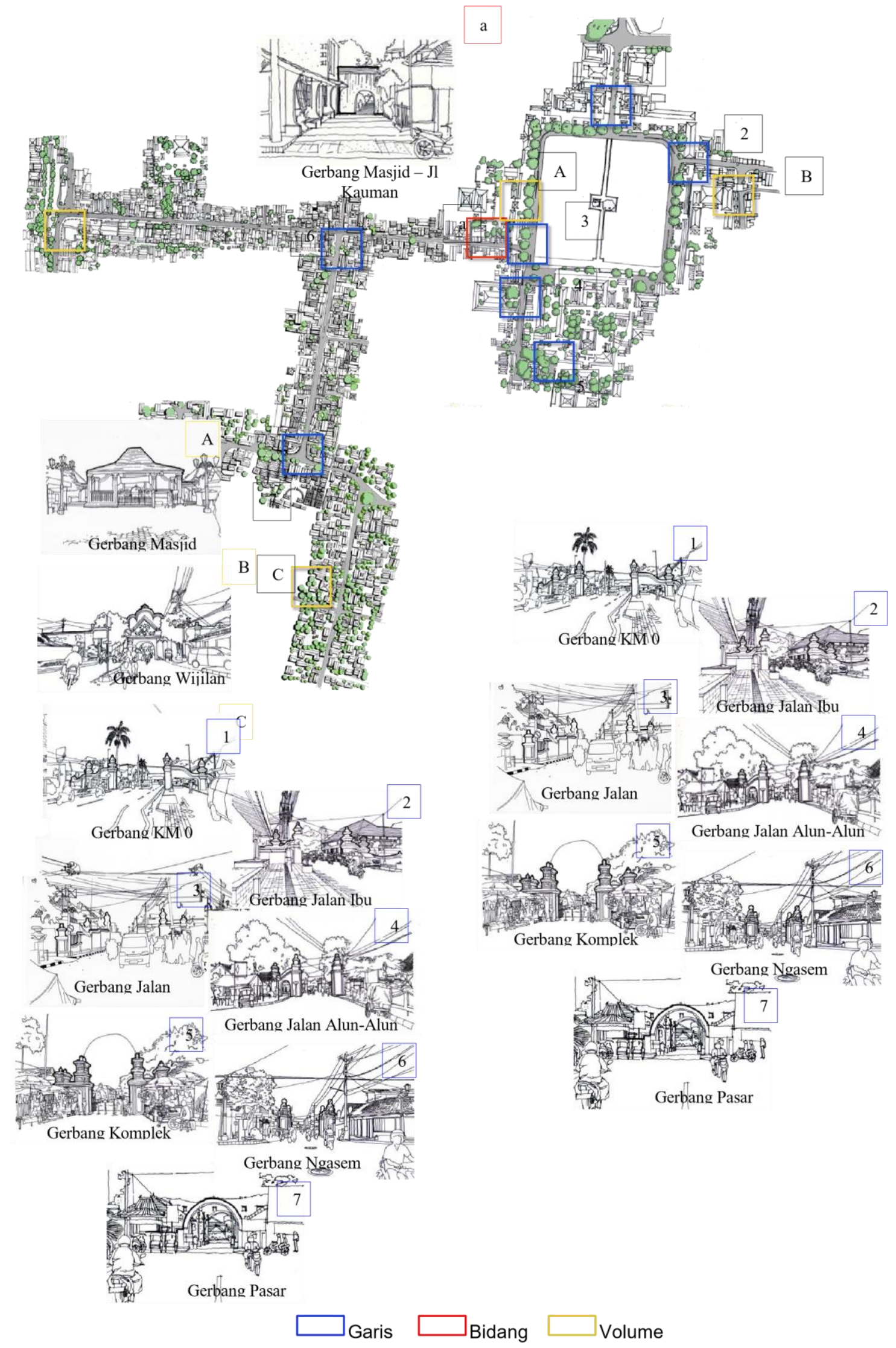

Figur 9 Peta Persebaran Klasifikasi Gerbang Berdasarkan Ekspresi Bentuk Pada Kawasan Keraton Yogyakarta 


\subsection{EKSISTENSI GERBANG DALAM MENCIPTAKAN MAKNA RUANG PADA KAWASAN KERATON CIREBON \& YOGYAKARTA}

Gerbang sebagai landmark kota tentu memiliki fungsi dan makna tertentu yang dibentuk dari eksistensi gerbang tersebut. Makna dapat diciptakan melalui aspek keestetikaan pada gerbang dan lingkungan sekitarnya. Ekspresi dari perletakkan, proporsi ruang terbuka dan bentuk dari sosok gerbang dapat membentuk sebuah eksistensi atau keberadaan yang memunculkan sebuah makna. Ditambahkan dengan pengalaman-pengalaman ruang yang dirasakan oleh pengamat akan memunculkan makna tersendiri yang mendukung eksistensi dari gerbang itu sendiri.

Tabel 4 Rekapitulasi Hasil Analisa Eksistensi Gerbang Keraton Cirebon

\begin{tabular}{|c|c|c|c|}
\hline Objek/Spot & Karakteristik & $\begin{array}{c}\text { Ekspresi Gerbang } \\
\text { Dan Ruang } \\
\text { Sekitarnya }\end{array}$ & Makna \\
\hline $\begin{array}{l}\text { 1. Gerbang Jalan Lemah } \\
\text { Wungku }\end{array}$ & $\begin{array}{l}\text { - Gerbang terletak pada simpul } \\
\text { terluar kawasan, dikelilingi } \\
\text { pedagang kaki lima, dua tugu } \\
\text { terpisah di sisi kiri dan kanan } \\
\text { - Ruang terbuka netral, namun } \\
\text { lebar gerbang hanya } \\
\text { memenuhi } 10 \% \text { lebar jalan } \\
\text { dan ketinggian gerbang } \\
\text { kurang dari bangunan } \\
\text { pelingkup } \\
\text { Bentuk gerbang dominan } \\
\text { dengan elemen garis yang } \\
\text { mengarah ke atas }\end{array}$ & $\begin{array}{l}\text { - } \text { Tidak } \\
\text { membatasi } \\
\text { ruang } \\
\text { - Eksistensi } \\
\text { gerbang kurang } \\
\text { terasa }\end{array}$ & $\begin{array}{l}\text { - Hanya } \\
\text { sebagai } \\
\text { tanda } \\
\text { - Tidak muncul } \\
\text { makna tertentu } \\
\text { - Sakral } \\
\text { (vertical } \\
\text { meaning) }\end{array}$ \\
\hline 2. Gerbang Jalan Kasepuhan & $\begin{array}{l}\text { - Gerbang terletak pada simpul } \\
\text { terluar kawasan, dua tugu } \\
\text { terpisah di sisi kiri dan kanan } \\
\text { - Salah satu tugunya terhalangi } \\
\text { seutuhnya oleh gerobak dan } \\
\text { pagar } \\
\text { - Ruang terbuka sangat luas } \\
\text { - Gerbang hanya memenuhi } \\
10 \% \text { dari lebar jalan } \\
\text { - Bentuk gerbang dominan } \\
\text { dengan elemen garis yang } \\
\text { mengarah ke atas }\end{array}$ & $\begin{array}{l}\text { - } \text { Tidak } \\
\text { membatasi } \\
\text { ruang } \\
\text { - Eksistensi } \\
\text { gerbang kurang } \\
\text { terasa }\end{array}$ & $\begin{array}{l}\text { - Hanya } \\
\text { sebagai } \\
\text { tanda } \\
\text { - Tidak muncul } \\
\text { makna tertentu } \\
\text { - Sakral } \\
\text { (vertical } \\
\text { meaning) }\end{array}$ \\
\hline $\begin{array}{l}\text { Gerbang Alun-Alun Seberang } \\
\text { Permukiman } \\
\end{array}$ & $\begin{array}{l}\text { - Gerbang terletak di sisi jalan, } \\
\text { seberang permukiman, dua } \\
\text { tugu disisi kiri dan kanan } \\
\text { membentuk vista } \\
\text { - Ruang terbuka sangat luas, } \\
\text { jika dilihat dari koridor jalan, } \\
\text { gerbang hanya memenuhi } \\
10 \% \text { dari lebar di salah satu } \\
\text { sisi jalan dengan ketinggian } \\
\text { yang setara dengan pelingkup } \\
\text { Bentuk gerbang dominan } \\
\text { oleh elemen garis mengarah } \\
\text { ke atas yang cukup tinggi. }\end{array}$ & $\begin{array}{l}\text { - Tenang/ } \\
\text { sunyi/ } \\
\text { hening } \\
\text { - Ruang yang } \\
\text { unik } \\
\text { - Adanya } \\
\text { hubungan } \\
\text { "vertikal" } \\
\text { Terasa } \\
\text { eksistensinya }\end{array}$ & $\begin{array}{l}\text { - Pengayom } \\
\text { - Khusyuk } \\
\text { - Sakral } \\
\text { (vertical } \\
\text { meaning) }\end{array}$ \\
\hline
\end{tabular}


The existential significance of ceremonial arches for the ...

\begin{tabular}{|c|c|c|c|}
\hline $\begin{array}{l}\text { 4. Gerbang Alun-Alun Seberang } \\
\text { Masjid }\end{array}$ & $\begin{array}{l}\square \text { Gerbang terletak di sisi jalan } \\
\text { seberang masjid, masjid } \\
\text { sebagai pemicu aktivitas } \\
\text { berdagang } \\
\text { disekitar spot ini }\end{array}$ & $\begin{array}{l}\text { - } \text { Ramai } \\
\text { - Tidak } \\
\text { membatasi ruang } \\
\text { - Kurang } \\
\quad \text { terasa } \\
\text { eksistensinya }\end{array}$ & $\begin{array}{l}\text { - } \text { Tidak muncul } \\
\text { makna tertentu } \\
\text { - Sakral } \\
\text { (vertical } \\
\text { meaning) }\end{array}$ \\
\hline
\end{tabular}

\begin{tabular}{|c|c|c|c|c|}
\hline & 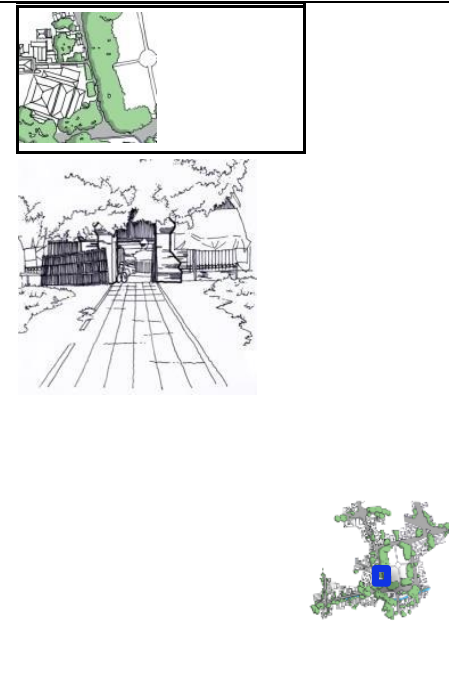 & $\begin{array}{l}\text { - Gerbang seutuhnya } \\
\text { terhalangi pedagang } \\
\text { kaki lima, dilihat dari } \\
\text { koridor jalan. } \\
\text { - Ruang terbuka kurang } \\
\text { terdefinisi } \\
\text { pelingkupnya, } \\
\text { perbandingan lebar } \\
\text { gerbang dengan jalan } \\
\text { adalah 0.125 dan } \\
\text { ketinggian yang setara } \\
\text { dengan bangunan masjid } \\
\text { - Bentuk gerbang } \\
\text { dominan oleh elemen } \\
\text { garis mengarah ke atas } \\
\text { yang cukup tinggi. }\end{array}$ & & \\
\hline & $\begin{array}{l}\text { Gerbang Alun-Alun Seberang } \\
\text { Keraton }\end{array}$ & $\begin{array}{l}\text { - Gerbang terletak di sisi } \\
\text { jalan seberang keraton, } \\
\text { keraton sebagai pemicu } \\
\text { aktivitas } \\
\text { berdagang disekitar spot } \\
\text { ini } \\
\text { - Gerbang seutuhnya } \\
\text { terhalangi pedagang } \\
\text { kaki lima, dilihat dari } \\
\text { koridor jalan. } \\
\text { - Ruang terbuka sangat } \\
\text { luas } \\
\text { - Bentuk } \\
\text { dominan oleh elemen } \\
\text { garis mengarah ke atas } \\
\text { yang cukup tinggi. }\end{array}$ & $\begin{array}{l}\text { - } \text { Ramai } \\
\text { - Atraktif } \\
\text { - Tidak } \\
\text { membatasi } \\
\text { ruang } \\
\text { - Eksistensi } \\
\text { kurang terasa }\end{array}$ & $\begin{array}{c}\text { - } \text { Tidak muncul } \\
\text { makna tertentu } \\
\text { - Sakral } \\
\text { (vertical } \\
\text { meaning) }\end{array}$ \\
\hline 6. & 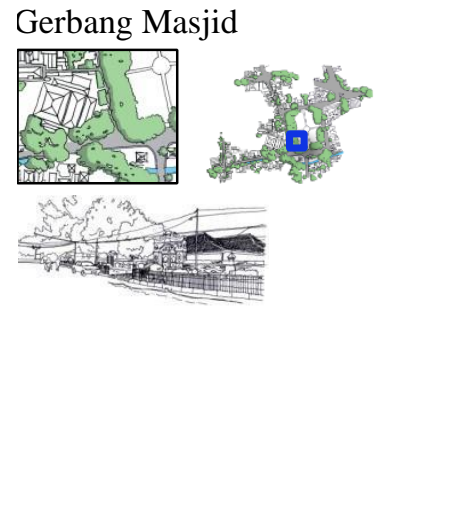 & $\begin{array}{l}\text { - Gerbang terletak di sisi } \\
\text { jalan } \\
\text { - Gerbang menyatu dengan } \\
\text { pagar mengelilingi } \\
\text { kavling bangunan } \\
\text { - Ruang terbuka sangat luas } \\
\text { - Proporsi gerbang dengan } \\
\text { ruang terbuka kurang } \\
\text { terasa } \\
\text { - Bentuk dominan } \\
\text { bervolume dan warna } \\
\text { mencolok }\end{array}$ & $\begin{array}{l}\text { - Masif } \\
\text { - Ramai } \\
\text { Kokoh } \\
\text { Eksistensi } \\
\text { cukup terasa }\end{array}$ & $\begin{array}{l}\text { - Bersahaja } \\
\text { - Perlindungan }\end{array}$ \\
\hline
\end{tabular}




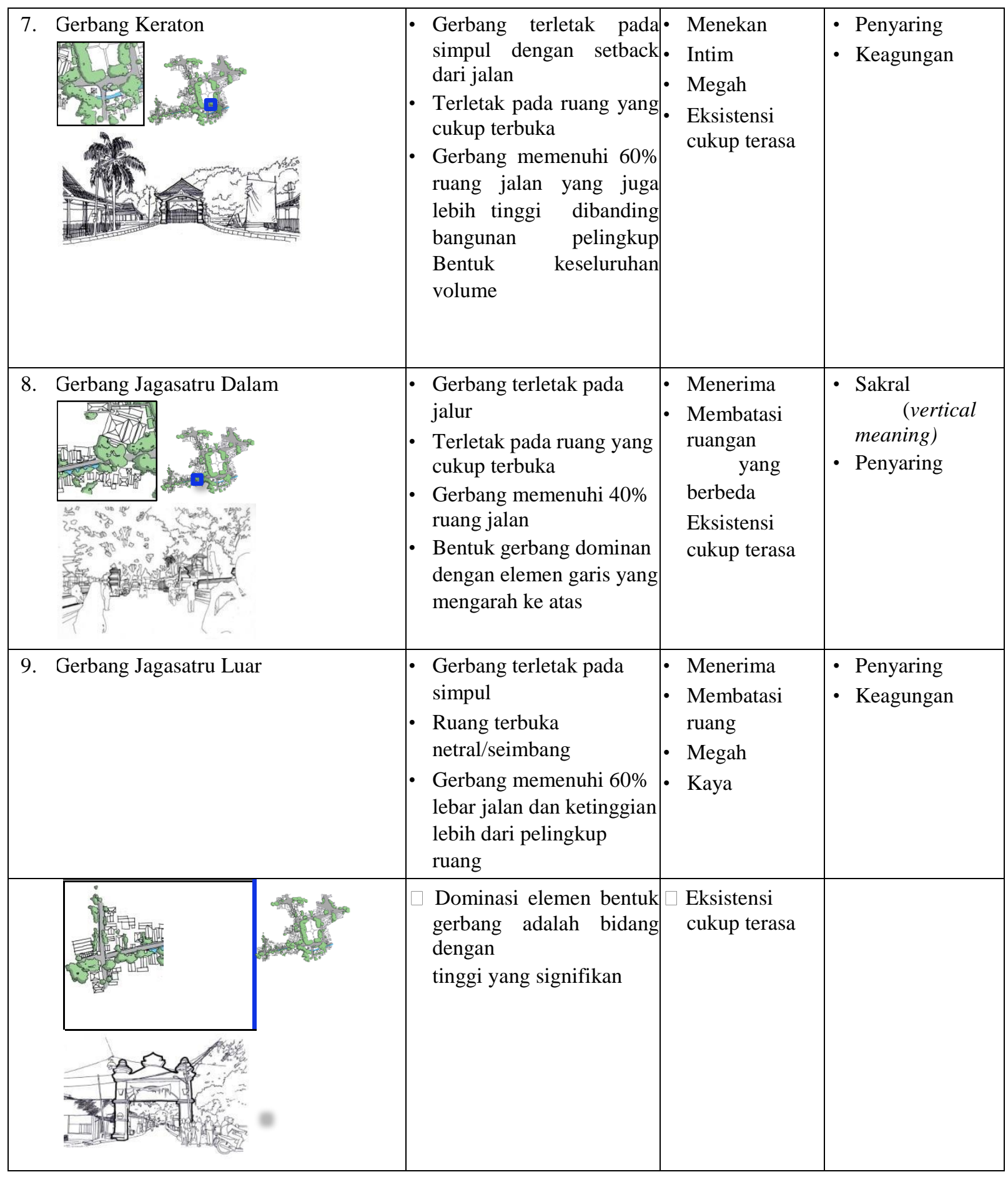


The existential significance of ceremonial arches for the ...

Tabel 5 Rekapitulasi Hasil Analisa Gerbang Kawasan Keraton Yogyakarta

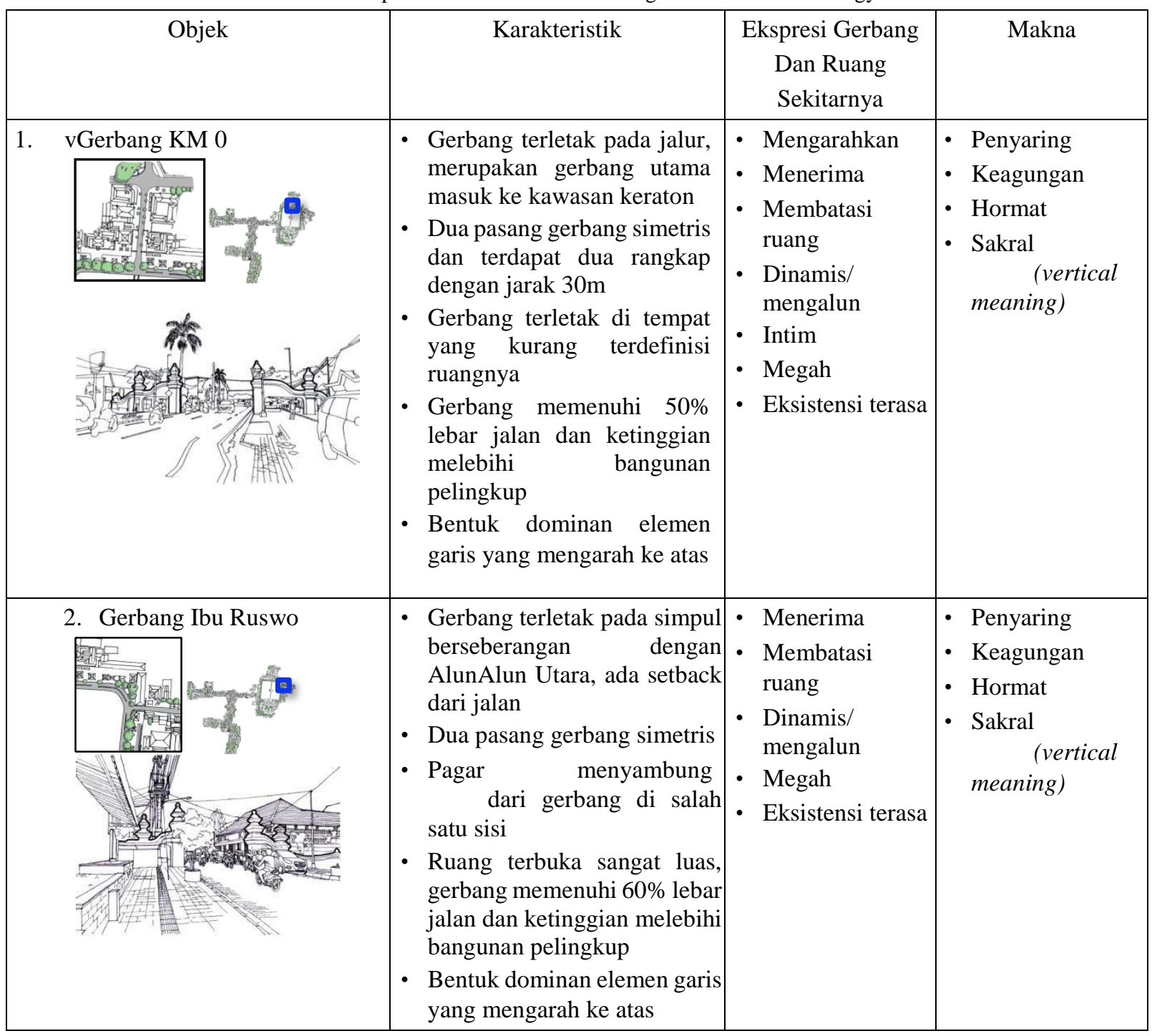

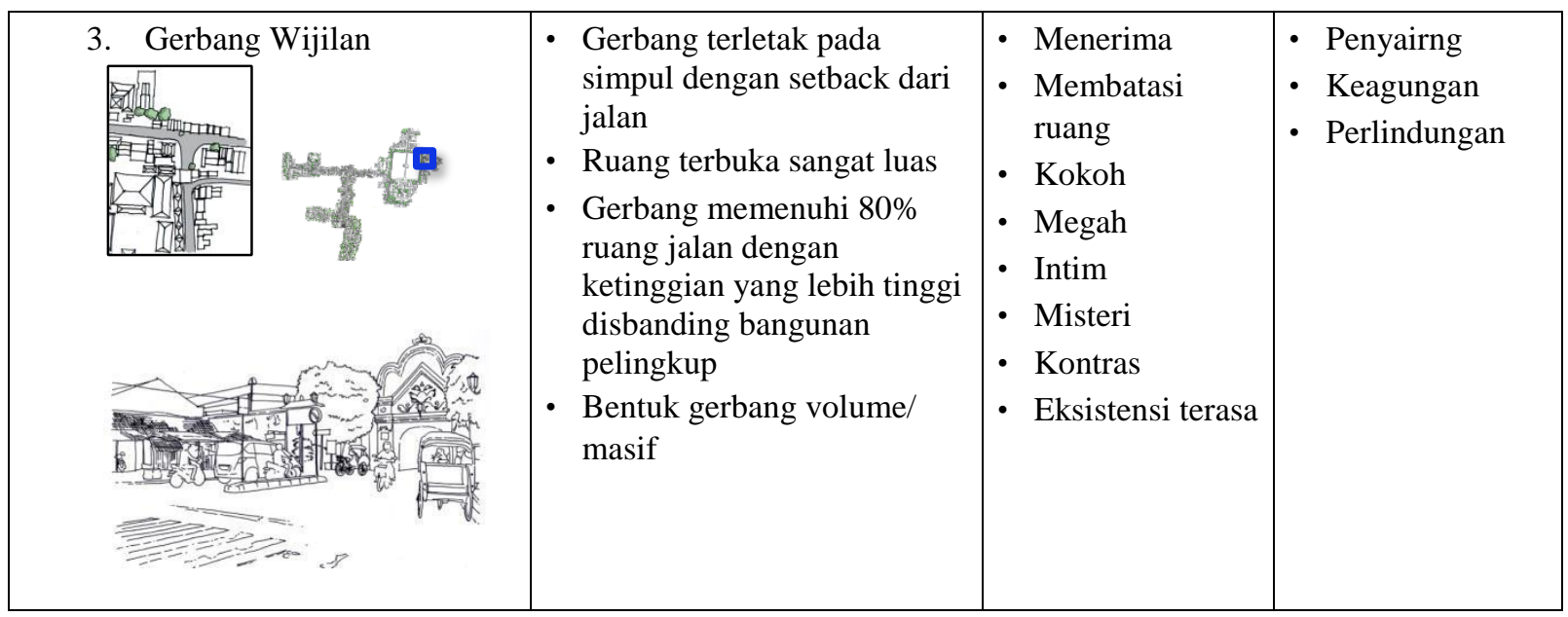




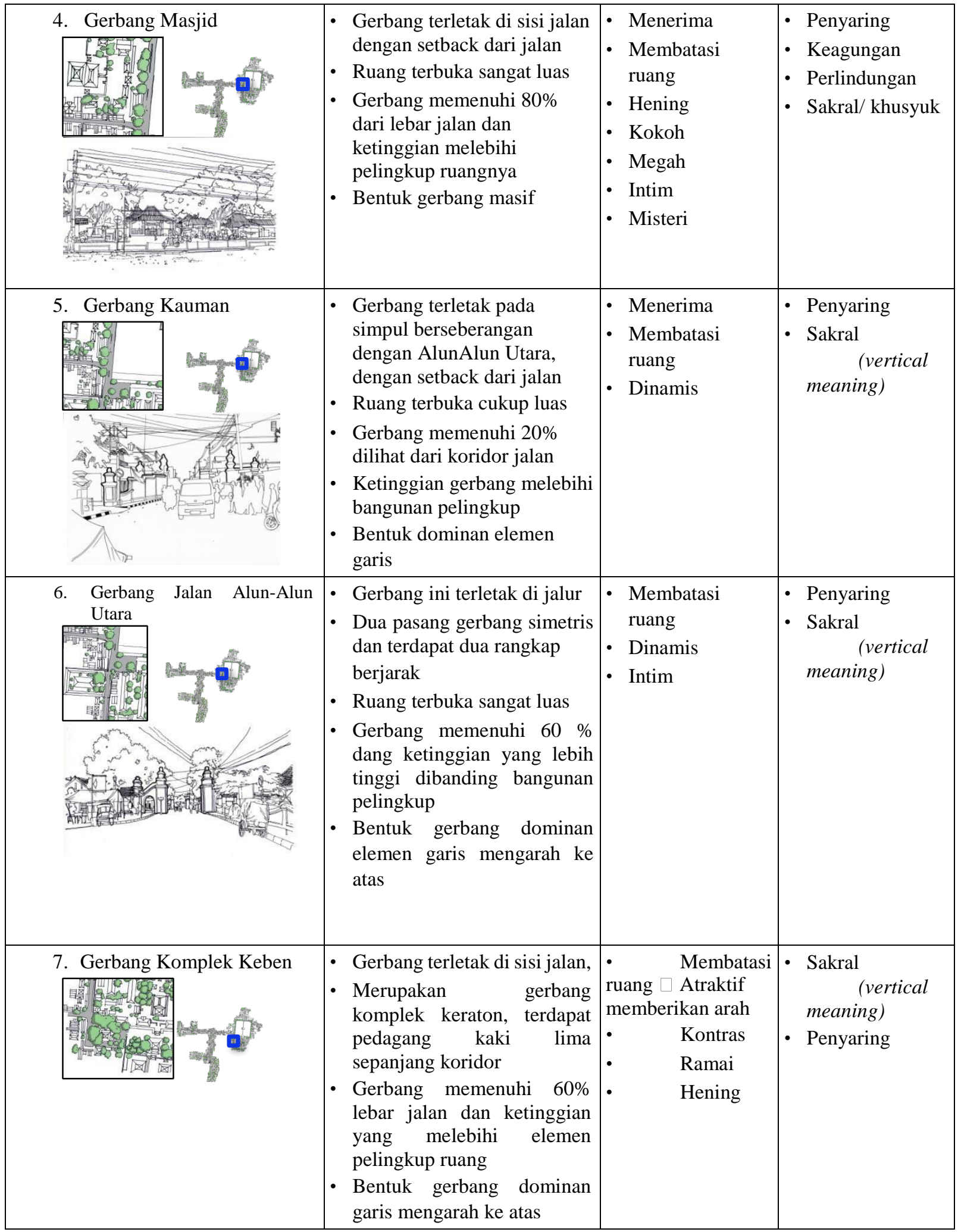


The existential significance of ceremonial arches for the ...

\begin{tabular}{|c|c|c|c|}
\hline $\begin{array}{l}\text { 8. } \\
\text { Kauman }\end{array}$ & $\begin{array}{l}\text { - Gerbang terletak di sisi jalan } \\
\text { dengan setback dari jalan } \\
\text { - Gerbang terletak pada } \\
\text { ruangan yang netral dengan } \\
\text { gerbang memenuhi } \\
\text { sepenuhnya ruang jalan } \\
\text { - Bentuk gerbang dominan } \\
\text { elemen bidang }\end{array}$ & $\begin{array}{l}\text { - } \text { Hening } \\
\text { - } \text { Intim } \\
\text { - } \text { Tegak } \\
\text { - } \text { Misteri } \\
\end{array}$ & $\begin{array}{l}\text { - Penyaring } \\
\text { - Sakral }\end{array}$ \\
\hline 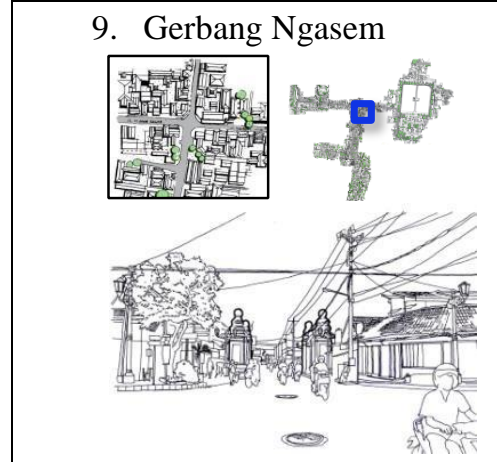 & $\begin{array}{l}\text { - } \text { Gerbang terletak di simpul } \\
\text { - Dua pasang gerbang } \\
\text { memanjang simetris terpisah } \\
\text { dikiri dan kanan jalan } \\
\text { - Ruang terbuka sangat luas } \\
\text { - Gerbang memenuhi } 40 \% \\
\text { lebar jalan dan ketinggian } \\
\text { melebihi bangunan pelingkup } \\
\text { - Bentuk dominan elemen garis } \\
\text { mengarah ke atas }\end{array}$ & $\begin{array}{l}\text { - Mengarahkan } \\
\text { - Intim } \\
\text { - Megah } \\
\end{array}$ & $\begin{array}{l}\text { - Sakral } \\
\text { (vertical } \\
\text { meaning) } \\
\text { - Keagungan }\end{array}$ \\
\hline 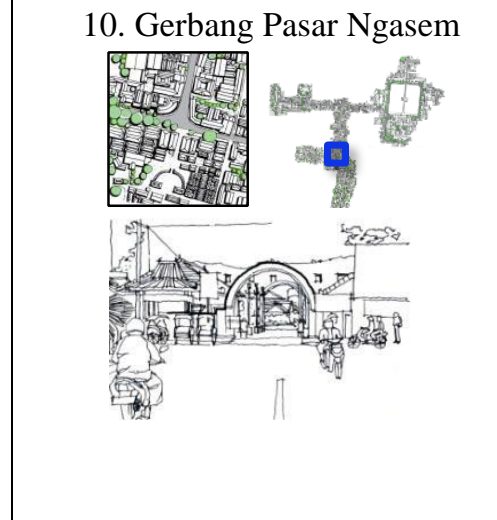 & $\begin{array}{l}\text { - Gerbang terletak pada } \\
\text { simpul, pandangan langsung } \\
\text { dari } \\
\text { koridor } \\
\text { - } \text { Ruang terbuka sangat luas } \\
\text { - } \text { Gerbang memenuhi } 60 \% \\
\text { ruang jalan dan ketinggian } \\
\text { yang setara dengan bangunan } \\
\text { pelingkup } \\
\text { - Bentuk gerbang dominan } \\
\text { elemen garis yang } \\
\text { melengkung }\end{array}$ & $\begin{array}{l}\text { - Mengarahkan } \\
\text { - Intim } \\
\text { - Hening/ Sunyi } \\
\end{array}$ & $\square$ Bersahaja \\
\hline 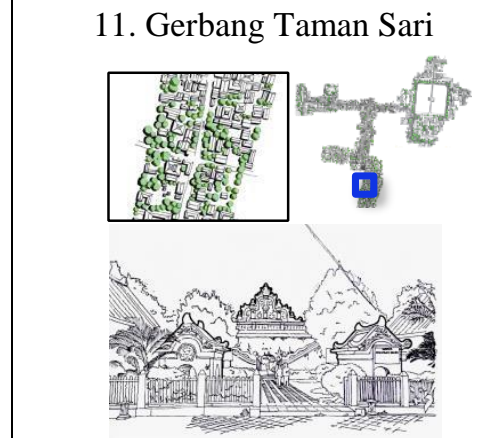 & $\begin{array}{l}\text { - Gerbang terletak pada sisi } \\
\text { jalan dengan setback cukup } \\
\text { jauh dari jalan } \\
\text { - Terdapat gerbang sebelum } \\
\text { gerbang ini } \\
\text { - Gerbang memenuhi } \\
\text { seutuhnya dari lebar jalan } \\
\text { dengan ketinggian yang lebih } \\
\text { tinggi dibandingkan elemen } \\
\text { pelingkup ruang }\end{array}$ & $\begin{array}{l}\text { - Megah } \\
\text { - Hening/ Sunyi } \\
\text { - Misteri } \\
\end{array}$ & $\begin{array}{l}\text { - Sakral } \\
\text { - Keagungan } \\
\text { - Perlindungan }\end{array}$ \\
\hline
\end{tabular}




\begin{tabular}{|l|l|l|l|}
\hline 12. Pojok Benteng & $\begin{array}{l}\text { Gerbang terletak pada } \\
\text { simpul jalan } \\
\text { Terletak pada ruang terbuka } \\
\text { yang kurang terasa meruang } \\
\text { Gerbang berbentuk masif }\end{array}$ & $\begin{array}{l}\text { Megah } \\
\text { Kokoh }\end{array}$ & Keagungan \\
Perlindungan
\end{tabular}

Berdasarkan hasil analisa yang telah dipaparkan diatas, makna adalah sebagai hasil akhir dari perwujudan ekspresi dari eksistensi gerbang dan ruang sekitarnya. Dimana perletakkan, proporsi dan bentuk berpengaruh pada pembentukan makna, namun bentuk merupakan aspek yang sangat penting untuk memunculkan makna tertentu dari gerbang dibandingkan dengan aspek lainnya.

\section{KESIMPULAN}

Gerbang adalah landmark sebagai elemen fisik perkotaan yang sangat penting. Peran gerbang adalah sebagai batas, pintu, dan penanda akan suatu perbedaan zona ataupun ruang. Namun, aspek sosial dan budaya turut kuat menjadikan suatu elemen fisik menjadi sebuah gerbang. Bentuk gerbang tidak hanya berupa gapura yang memiliki atap, namun dapat berupa tugu baik sepasang secara simetri di kiri dan kanan jalan maupun satu tugu saja. Satu buah tugu yang berbentuk monumental di Kawasan Keraton Yogyakarta yang disebut Pojok Benteng, secara sosial dan budaya masyarakat setempat, Pojok Benteng ini memiliki peran seperti gerbang lainnya di Kawasan Keraton Yogyakarta.

Dari hasil analisis masing-masing spot gerbang di kedua Kawasan Cirebon dan Yogyakarta, dapat disimpulkan bahwa gerbang-gerbang pada kawasan Keraton Yogyakarta lebih menunjukkan adanya eksistensi dari pada di Kawasan Cirebon. Hal tersebut menunjukkan bahwa Kawasan Keraton Yogyakarta lebih menjaga identitas monarki yang diimplementasikan terhadap elemen fisik terutama gerbang sebagai landmark. Sedangkan pada Kawasan Keraton Cirebon menunjukkan sikap acuh terhadap kepemilikan atau artefak peninggalan kerajaan atau monarki, dilihat dari kurangnya eksistensi gerbang. 


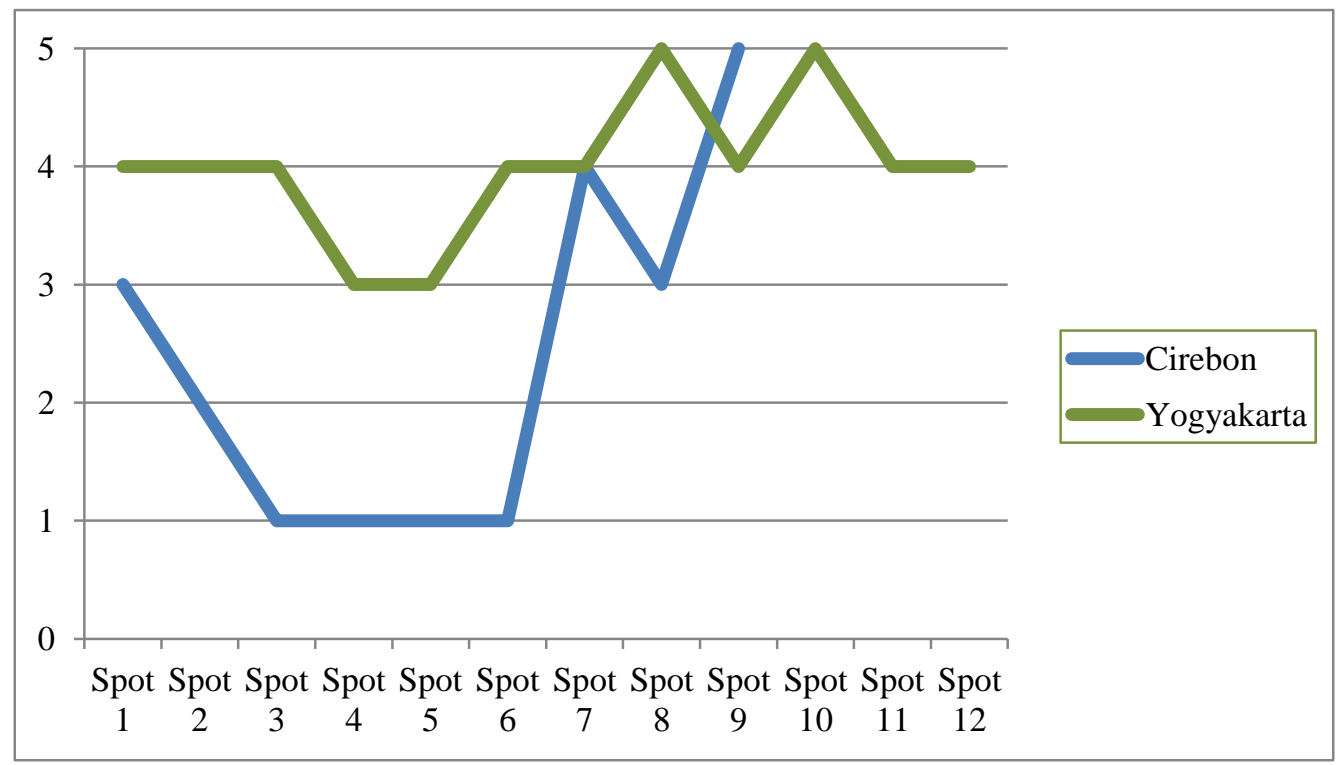

Figur 10 Grafik Tingkat Eksistensi Gerbang Kawasan Keraton CIrebon dan Yogyakarta

Namun, pemunculan makna sangat kuat dimunculkan oleh bentuk dari sosok gerbang itu sendiri. Bentuk-bentuk itulah yang menjadi garis merah peng-implementasian identitas terhadap elemen fisik perkotaan yang dapat menjadikan citra sebuah kota.

\section{WACANA LANJUTAN}

Penataan sebuah kota haruslah sesuai dan mengikuti kaidah estetika lingkungan perkotaan termasuk penataan ruang kota Cirebon dan Yogyakarta. Penataan ruang kota itu diantaranya harus tetap memperhatikan keberadaan elemenn - elemen fisik terutama gerbang sebagai landmark yang dapat menciptakan citra kota. Dari kesimpulan yang diangkat, penulis menyarankan untuk dilakukan penelitian secara terstruktur untuk mengetahui makna yang ditimbulkan melalui bentuk gerbang dikarenakan bentuk merupakan aspek penting dalam pemunculan suatu makna tertentu.

\section{DAFTAR PUSTAKA}

Norberg-Schulz, Christian. (1971). Existence, Space \& Architecture, Cambridge MA: MIT Press. Cullen, Gordon. (1973). The Concise Townscape, Architectural Press: London.

Lynch, Kevin. (1960). The Image of the City, Cambridge MA: MIT Press.

Pangarso, F. X. Budiwidodo. (2004). Estetika Lingkungan Perkotaan: Introduksi (bahan kuliah)

Smithies, K. W. (1981). Principles of Design in Architecture. New York: Van Nostrand Reinhold Company Inc.

Pangarso, FX. Budiwidodo (2015). Indikasi Keestetikaan Lingkungan Perkotaan Kawasan Pusat Kota Wonosari Kabupaten Gunungkidul Daerah Istimewa Yogyakarta. Bandung: Skripsi Arsitektur Unpar.

Pangarso, FX. Budiwidodo (2013). Indikasi Keestetikaan Lingkungan Perkotaan Pada Ruas Koridor Jalan Di Tepian Selokan Mataram dan Ruas Koridor di Jalan Kawasan Ngasem, Yogyakarta. Bandung: Skripsi Arsitektur Unpar 